\title{
Thyroid Hormones and Growth in Health and Disease
}

\author{
Ömer Tarım \\ Uludağ University Faculty of Medicine, Division of Pediatric Endocrinology, Bursa, Turkey
}

\begin{abstract}
Thyroid hormones regulate growth by several mechanisms. In addition to their negative feedback effect on the stimulatory hormones thyrotropin-releasing hormone (TRH) and thyrotropin (TSH), thyroid hormones also regulate their receptors in various physiological and pathological conditions. Up-regulation and down-regulation of the thyroid receptors fine-tune the biological effects exerted by the thyroid hormones. Interestingly, the deiodinase enzyme system is another intrinsic regulator of thyroid physiology that adjusts the availability of thyroid hormones to the tissues, which is essential for normal growth and development. Almost all chronic diseases of childhood impair growth and development. Every disease may have a unique mechanism to halt linear growth, but reduced serum concentration or diminished local availability of thyroid hormones seems to be a common pathway. Therefore, the effects of systemic diseases on thyroid physiology must be taken into consideration in the evaluation of growth retardation in affected children.
\end{abstract}

Key words: Thyroid, growth, children Conflict of interest: None declared

Received: 27.01.2011
Accepted: 19.02.2011

\section{Introduction}

Thyroid hormones, along with insulin, growth hormone, glucocorticoids, insulin-like growth factor-1 (IGF-1) and other hormones, regulate body protein metabolism and, thereby, are closely linked to the processes involved in growth and development. This paper reviews the literature about the regulatory role of thyroid hormones in growth, in health and disease and concentrates on common clinical problems that can alter thyroid hormone status and, therefore, may play an important role in growth retardation observed in such conditions.

Role of the Thyroid Gland in Normal Growth

The first clues for a role of thyroid hormones in the regulation of cell proliferation were obtained from observations on amphibian metamorphosis. These observations have also revealed that other hormones including insulin, glucocorticoids, growth hormone and prolactin participate in cell proliferation by antagonizing the effect of thyroxine $\left(T_{4}\right)$, at least in amphibians $(1,2,3,4)$. During the process of development, apoptosis and cellular proliferation are balanced by this multihormonal mechanism, the major actor of which is triiodothyronine $\left(T_{3}\right)(5,6)$. Animal studies have demonstrated that $T_{3}$ is a liver mitogen and promotes proliferation of hepatocytes, if given after partial hepatectomy and, its effect depends on the type and developmental state of the cell $(7,8) . T_{3}$ also has positive effects on wound healing and on proliferation of cells, including cultured bovine thyroid cells, bone marrow pro-B cells, pancreatic acinar cells and renal proximal tubular epithelial cells $(9,10,11,12,13)$. There are indications that $T_{3}$ is required for branching morphogenesis and epithelial/mesenchymal differentiation of the lungs (14).

Address for Correspondence

Ömer Tarım MD, Uludağ University Faculty of Medicine, Division of Pediatric Endocrinology, Bursa, Turkey

Gsm: +90 5324459426 Fax: +90 2242450666 E-mail: drotarim@gmail.com

OJournal of Clinical Research in Pediatric Endocrinology, Published by Galenos Publishing. 
Finally, $T_{3}$ influences directly the linear growth, which may be via its stimulating effect on DNA synthesis in osteoblasts and in other cells (15). In contrast, $T_{3}$ treatment has been reported to block proliferation and induce differentiation of oligodendrocyte progenitor cells, neuroblastoma N2a/b cells, and erythroid progenitors $(16,17,18)$.

Previous research has demonstrated that approximately 149 genes, including fibrinogen, transferrin, fibronectin (FN), androgen receptor (AR)-associated protein (ARA70), and dehydroepiandrosterone sulfotransferase family $1 \mathrm{~A}$ member 2 (SULT2A1) genes, are positively regulated by $T_{3}$. $\mathrm{T}_{3}$-target genes were investigated by microarray assay in hepatocellular carcinoma cell lines, and genes involved in metabolism, detoxification, signal transduction, cell adhesion and cell migration, as well as transcription factors, oncogenes, and the cell cycle were recognized to be up-regulated by treatment with $\mathrm{T}_{3}(2)$.

$\mathrm{T}_{3}$ and its nuclear receptors modify expression of different genes/proteins involved in cell cycle control. This effect extends from growth factors [such as epidermal growth factor (EGF) and transforming growth factor (TGF)- $\beta$ ], to cell surface receptors (EGFR) as well as to proteins acting at the cell membrane level (Ras), various transcription factors (c-Fos, c-Myc, E2F1), cyclins, Cip/Kip family of cdk2 inhibitors, and p53 inhibitor Mdm2. The effect of thyroid hormones on these genes seems to vary with the type and developmental state of the cell and whether it is a normal or tumor cell (19).

The biological effects of $T_{3}$ depend on various factors including amount of bioavailable hormone, levels of different thyroid receptor (TR) isoforms and of post-transcriptional modifications of TRs, type of their heterodimerization partners - retinoid $X$ receptors (RXRs), interaction with co-repressors and co-activators, and on the structure of thyroid hormone response elements (TREs) in the target gene promoters $(20,21,22,23,24,25,26)$.

The deiodinase (D) enzyme system is an important regulator of thyroid status via both pre- and posttranslational mechanisms that consequently play a significant role in regulating the availability of thyroid hormones to the tissues $(27,28)$. As discussed in an extensive review by Germain et al (29), there are three types of D (D1, D2, D3) with different properties in terms of their activity in various tissues and their roles in states of hypothyroidism and hyperthyroidism. The activities of D2 and D3 are designed to maintain local tissue $T_{3}$ content as normal as possible in the face of altered serum hormone levels. In states of iodine deficiency and hypothyroidism, in order to maintain the available amount of $\mathrm{T}_{3}$ within the normal range, D2 activity is markedly up-regulated and D3 activity is decreased to increase the proportion of $T_{3}$ formed locally and to lessen its degradation $(30,31)$. Opposite changes in
D2 and D3 activity occur in hyperthyroidism (32). Thyrotropin (TSH) stimulation of the thyroid gland in primary hypothyroidism results in increased D1 activity, which may serve to increase the conversion of $T_{4}$ to $T_{3}$ (33).

The deiodinases are also important determinants of alterations in systemic thyroid hormone levels observed in illness and nutritional deficiency. Euthyroid sick syndrome or non-thyroidal illness is considered as an adaptive response of the organism, although this definition is still controversial $(34,35)$. Serum $T_{4}$ and $T_{3}$ levels are markedly decreased without a compensatory rise in the serum TSH level during severe illness and nutritional deficiency $(36,37,38)$, leading to a significant decline in basal metabolic rate along with a decrease in protein and fat catabolism $(39,40)$. Alterations in deiodinase activity have been postulated to be responsible for this adaptive suppression of the thyroid axis. Decreases in hepatic D1 activity and increases in hepatic and skeletal muscle D3 activity have been reported in this setting $(36,41)$. On the other hand, more recent research has implied that alterations in $D$ activity may be a consequence rather than a cause of the decrease in the serum $T_{3}$ level $(42,43)$. It was demonstrated that administration of supraphysiological amounts of $T_{4}$ and/or $T_{3}$ to rabbits with systemic illness was necessary to regulate the serum concentrations of these hormones, suggesting that enhanced hormonal degradation and/or excretion, rather than diminished thyroidal secretion or decreased $T_{4}$ to $T_{3}$ conversion, had a dominant role in the response to non-thyroidal illness (44).

Recent research has suggested that induction of D3 activity in response to tissue injury and inflammation, due to hypoxic or oxidative stress, may influence healing or regenerative processes $(45,46,47)$. However, more studies are needed to confirm these results.

\section{Thyroid and Growth in Disease}

Hypothyroidism is a well-known cause of growth retardation. Height prognosis in children with latediagnosed congenital hypothyroidism is guarded. Although treatment leads to an initial catch-up growth spurt, prolonged hypothyroidism may result in compromised adult height (48). On the other hand, hyperthyroidism has been reported to accelerate growth in normal children and in patients with Turner syndrome (49). However, whether this temporary growth spurt increases final height is not known.

\section{Thyroid Physiology in Systemic Disease}

Taking into account the important role of thyroid hormones in the regulation of growth, alterations in thyroid physiology must also be considered when evaluating the growth of a child with systemic disease.

\section{Thyroid Function in Neuropsychiatric Disease}

Depression causes a blunted TSH response to thyrotropin-releasing hormone (TRH) stimulation and 
the expected nocturnal rise in TSH may be absent or diminished. The peripheral conversion of $T_{4}$ to $T_{3}$ is also decreased, a finding consistent with non-thyroidal illness or euthyroid sick syndrome (50). Lithium, used as a therapeutic agent in depression and psychosis, is notorious for causing hypothyroidism (51).

Euthyroid sick syndrome may also occur in anorexia nervosa. The abnormal thyroid functions frequently include a low $T_{3}$, high reverse $T_{3}\left(r T_{3}\right)$, normal or low $T_{4}$, low-normal free $T_{4}\left(\mathrm{fT}_{4}\right)$, and normal TSH (52). The TSH response to $\mathrm{TRH}$ and the iodine uptake on thyroid scan are often diminished. Even after a successful treatment of anorexia nervosa, the recovery period for thyroid hormones, particularly for $T_{3}$, may be prolonged (53). Therefore, growth velocity of patients with anorexia nervosa may not normalize immediately after weight gain. On the other hand, thyroid hormone treatment has also been advocated for patients with anorexia nervosa. It is doubtful that exogenous thyroid hormone can maintain normal growth in a state of energy deprivation.

Long-term medications for various entities must be carefully assessed for their possible side effects on thyroid functions. Methylphenidate, used for the treatment of attention deficit hyperactivity disorder, may cause modest reductions in serum $\mathrm{T}_{4}$ and $\mathrm{TSH}$ levels $(1,54)$. However, it has also been reported that the serum concentrations of these hormones remain within normal range and that height, weight, body mass index (BMI), IGF-1, and IGF binding protein-3 (IGFBP-3) values are not significantly affected (54). Many antiepileptic drugs also cause modest suppression of the hypothalamic-pituitary-thyroid axis, but clinical hypothyroidism is not reported $(1,54)$. The long-term effects of such medication on linear growth remain to be elucidated.

\section{Thyroid Functions in Hepatogastrointestinal Disease}

Since the liver is the major organ responsible for the metabolism and clearance of hormones, liver disease affects the serum concentration and activity of the hormones. Serum $T_{4}$ concentration is increased in acute hepatitis, but clinical hyperthyroidism does not occur. This is due to the decreased clearance of $\mathrm{T}_{4}$ and to an increase in $T_{4}$-binding globulin ( $T B G$ ) levels as part of the acute-phase response to inflammation. The release of presynthesized TBG from damaged hepatocytes into the circulation is another cause of increment in TBG levels in these patients $(55,56,57)$. Because $T_{4}$ and $T B G$ are increased simultaneously, hyperthyroidism is rarely a problem. Total and free $T_{3}$ are usually decreased and $\mathrm{rT}_{3}$ increased in acute hepatitis. However, $\mathrm{T}_{3}, \mathrm{~T}_{4}$, and $\mathrm{TSH}$ may all be suppressed in fulminant hepatitis $(58,59)$.

Autoimmune liver disease may be associated with Hashimoto's thyroiditis. Serum $T_{3}$ is decreased in chronic liver disease due to the diminished activity of the hepatic enzyme 5-monodeiodinase, leading to reduced conversion of $T_{4}$ to $T_{3}$. Although total $T_{4}$ is reduced, $f T_{4}$ is usually normal (58).

Certain medications used in liver disease may also alter thyroid function. Dexamethasone and propranolol inhibit D1 and contrast media used in cholangiography such as iopanoic acid and ipodate block the activity of both D1 and D2. All these medications reduce peripheral conversion of $T_{4}$ to $T_{3}$ and diminish clearance of $T_{4}$, leading to increased $T_{4}$ and decreased $T_{3}$ concentrations. Consequently, serum $r T_{3}$ and TSH are increased $(60,61)$.

\section{Thyroid Functions in Renal Disease}

Similar to liver disease, peripheral conversion of $T_{4}$ to $T_{3}$ is diminished in chronic renal failure. Serum $T_{4}$ and $T_{3}$ levels are usually decreased, but unlike other systemic conditions that cause euthyroid sick syndrome, $\mathrm{rT}_{3}$ is usually normal. The plasma TBG level is also usually normal, but $\mathrm{TSH}$ response to $\mathrm{TRH}$ and the thyroid response to TSH are reduced. Radioactive iodine uptake by the thyroid gland may be reduced, probably due to the increased serum concentration of free iodine which dilutes the radiolabeled iodine $(62,63,64)$

\section{Thyroid Functions in Malnutrition and Obesity}

Serum TSH and TSH response to TRH have been reported to be diminished with acute fasting in adults $(65,66)$. Adolescents with growth failure due to fear of obesity show a delayed TSH response to TRH (67). TSH response to $\mathrm{TRH}$ may be normal or delayed in patients with anorexia nervosa and nutritional dwarfing. Studies in both children and rats have demonstrated reduced $T_{3}$ and increased $\mathrm{rT}_{3}$ in this setting $(67,68,69)$.

Serum $T_{4}, T_{3}, \mathrm{fT}_{4}$, and TSH concentrations were reported to be normal in exogenous obesity (70). However, more recent research findings indicate that serum $\mathrm{fT}_{4}$ is inversely and TSH is positively correlated with BMI, suggesting a state of subclinical hypothyroidism despite the presence of serum hormone concentrations within the normal range (71).

\section{Conclusion}

Although thyroid functions are affected by many systemic diseases, growth retardation in these conditions is often multifactorial and it is difficult to attribute the retardation to thyroid dysfunction per se. The hypothalamicpituitary-IGF-1 axis as well as the target tissues are also adversely affected in most of the conditions discussed above. Therefore, mechanisms that regulate growth during disease processes are complicated. Interactions within the endocrine system as well as the cross-talk between the immune, neuronal, and endocrine systems remain to be further elucidated to understand and manage the growth retardation associated with specific diseases. 


\section{References}

1. Tarim O. Abnormal endocrine test results due to non-endocrine condirtions. In: Lifshitz $F$ (ed). Pediatric Endocrinology. 5th edition. Informa Health Care, NY, London, 2007: 581-595.

2. Liu Z, Long W, Fryburg DA, Barrett EJ. The Regulation of Body and Skeletal Muscle Protein Metabolism by Hormones and Amino Acids. J Nutr 2006;136:212-217.

3. Dickhoff WW, Brown CL, Sullivan CV, Bern HA. Fish and amphibian models for developmental endocrinology. J Exp Zool Suppl 1990;4:90-97.

4. Kikuyama S, Kawamura K, Tamaka S, Yamamoto K. Aspects of amphibian morphogenesis: hormonal control. Int Rev Cytol 1993;145:105-148.

5. Tata JR. Amphibian metamorphosis as a model for the developmental actions of thyroid hormones. Mol Cell Endocrinol 2006;246:10-20.

6. Su Y, Damjanovski S, Shi Y, Shi YB. Molecular and cellular basis of tissue remodeling during amphibian metamorphosis. Histol Histopathol 1999;14:175-183.

7. Francavilla A, Carr BI, Azzarone A, Polimeno L, Wang Z, Van Thiel DH, Subbotin V, Prelich JG, Starzl TE. Hepatocyte proliferation and gene expression induced by triiodothyronine in vivo and in vitro. Hepatology 1994;20:1237-1241.

8. Malik R, Mellor N, Selden C, Hodgson H. Triiodothyronine enhances the regenerative capacity of the liver following partial hepatectomy. Hepatology 2003;37:79-86.

9. Safer JD, Crawford TM, Holick MF. Topical thyroid hormone accelerates wound healing in mice. Endocrinology 2005;146:4425-4430.

10. Di Fulvio M, Coleoni AH, Pellizas CG, Masini-Repiso AM. Tri-iodothyronine induces proliferation in cultured bovine thyroid cells: evidence for the involvement of epidermal growth factor-associated tyrosine kinase activity. J Endocrinol 2000;166:173-182.

11. Foster MP, Montecino-Rodriguez E, Dorshkind $\mathrm{K}$. Proliferation of bone marrow pro-B cells is dependent on stimulation by the pituitary/thyroid axis. J Immunol 1999;163:5883-5890.

12. Ohmura T, Katyal SL, Locker J, Ledda-Columbano GM, Columbano A, Shinozuka H. Induction of cellular DNA synthesis in the pancreas and kidneys of rats by peroxisome proliferators, 9-cis retinoic acid, and 3,3' 5-triiodo-L-thyronine. Cancer Res 1997:57:795-798.

13. Ledda-Columbano GM, Perra A, Pibiri M, Molotzu F, Columbano A. Induction of pancreatic acinar cell proliferation by thyroid hormone. J Endocrino 2005;185:393-399.

14. Archavachotikul K, Ciccone TJ, Chinoy MR, Nielsen HC, Volpe MV. Thyroid hormone affects embryonic mouse lung branching morphogenesis and cellular differentiation. Am J Physiol Lung Cell Mol Physiol 2002;282:359-369.

15. Kassem M, Mosekilde L, Eriksen EF. Effects of triiodothyronine on DNA synthesis and differentiation markers of normal human osteoblast-like cells in vitro. Biochem Mol Biol Int 1993;30:779-788.

16. Baas D, Bourbeau D, Sarlieve LL, Ittel ME, Dussault JH, Puymirat J. Oligodendrocyte maturation and progenitor cell proliferation are independently regulated by thyroid hormone. Glia 1997:19:324-332.

17. Garcia-Silva S, Perez-Juste G, Aranda A. Cell cycle control by the thyroid hormone in neuroblastoma cells. Toxicology 2002;181-182:179-182.
18. Bauer A, Mikulits W, Lagger G, Stengl G, Brosch G, Beug $H$. The thyroid hormone receptor functions as a ligandoperated developmental switch between proliferation and differentiation of erythroid progenitors. EMBO J 1998;17:4291-4303.

19. Huang YH, Tsai MM, Lin KH. Thyroid Hormone Dependent Regulation of Target Genes and Their Physiological Significance. Chang Gung Med J 2008;31:325-334.

20. Cheng SY. Isoform-dependent actions of thyroid hormone nuclear receptors: lessons from knocking mutant mice. Steroids 2005;70:450-454.

21. Chen SL, Chang YJ, Wu YH, Lin KH. Mitogen-activated protein kinases potentiate thyroid hormone receptor transcriptional activity by stabilizing its protein. Endocrinology 2003;144:1407-1419.

22. Lin HY, Hopkins R, Cao HJ, Tang HY, Alexander C, Davis FB, Davis PJ. Acetylation of nuclear hormone receptor superfamily members: thyroid hormone causes acetylation of its own receptor by a mitogen-activated protein kinase-dependent mechanism. Steroids 2005:70:444-449.

23. Rastinejad F. Retinoid $X$ receptor and its partners in the nuclear receptor family. Curr Opin Struct Biol 2001:11:33-38.

24. Szanto A, Narkar V, Shen Q, Uray IP, Davies PJ, Nagy L. Retinoid $X$ receptors: $X$-ploring their (patho)physiological functions. Cell Death Differ 2004;11:126-143.

25. Chen JD, Evans RM. A transcriptional co-repressor that interacts with nuclear hormone receptors. Nature 1995;377:454-457.

26. Onate SA, Tsai SY, Tsai MJ, O'Malley BW. Sequence and characterization of coactivator for the steroid hormone receptor superfamily. Science 1995;270:1354-1357.

27. Bianco AC, Salvatore D, Gereben B, Berry MJ, Larsen PR. Biochemistry, cellular and molecular biology, and physiological roles of the iodothyronine selenodeiodinases. Endocr Rev 2002:23:38-89.

28. Zavacki AM, Ying $H$, Christoffolete MA, Aerts G, So E, Harney JW, Cheng SY, Larsen PR, Bianco AC. Type 1 iodothyronine deiodinase is a sensitive marker of peripheral thyroid status in the mouse. Endocrinology 2005:146:1568-1575.

29. Germain DLS, Galton VA, and Hernandez A. Defining the Roles of the lodothyronine Deiodinases: Current Concepts and Challenges. Endocrinology 2009:150:1097-1107.

30. Peeters R, Fekete C, Goncalves C, Legradi G, Tu HM, Harney JW, Bianco AC, Lechan RM, Larsen PR. Regional physiological adaptation of the central nervous system deiodinases to iodine deficiency. Am J Physiol 2001:281:54-61.

31. Escobar-Morreale HF, Obregon MJ, Hernandez A, Escobar del Rey F, Morreale de Escobar G. Regulation of iodothyronine deiodinase activity as studied in thyroidectomized rats infused with thyroxine or triiodothyronine. Endocrinology 1997;138:2559-2568.

32. van Doorn J, Roelfsema F, van der Heide D. Conversion of thyroxine to 3,5,3?-triiodothyronine in several rat tissues in vivo: the effect of hypothyroidism. Acta Endocrinol (Copenh) 1986:113:59-64.

33. Beech SG, Walker SW, Arthur JR, Lee D, Beckett GJ. Differential control of type-I iodothyronine deiodinase expression by the activation of the cyclic AMP and phosphoinositol signalling pathways in cultured human thyrocytes. J Mol Endocrinol 1995:14:171-177.

34. Van den Berghe G, Baxter RC, Weekers F, Wouters $P$, Bowers CY, Iranmanesh A, Veldhuis JD, Bouillon R'. The combined administration of $\mathrm{GH}$-releasing peptide-2 (GHRP-2), TRH and GnRH to men with prolonged critical illness evokes superior endocrine and metabolic effects compared to treatment with GHRP-2 alone. Clin Endocrinol (Oxf) 2002;56:655-669. 
35. Van den Berghe G, Wouters P, Weekers F, Mohan S, Baxter RC, Veldhuis JD, Bowers CY, Bouillon R. Reactivation of pituitary hormone release and metabolic improvement by infusion of growth hormone-releasing peptide and thyrotropin-releasing hormone in patients with protracted critical illness. J Clin Endocrinol Metab 1999:84:1311-1323

36. DeGroot LJ. Nonthyroidal illness syndrome. In: DeGroot LJ, Jameson JL, eds. Endocrinology. 5th ed. Philadelphia: Elsevier; 2006;2101-2112.

37. Kmiec Z, Kotlarz G, Smiechowska B, Mysiwski A. Thyroid hormones homeostasis in rats refed after short-term and prolonged fasting. J Endocrinol Invest 1996;19:304-311.

38. Boelen A, Wiersinga WM, Fliers E. Fasting-induced changes in the hypothalamus-pituitary-thyroid axis. Thyroid 2008;18:123-129.

39. Wells $S$, Campbell R. Decrease in resting metabolic rate during rapid weight loss is reversed by low dose thyroid hormone treatment. Metabolism 1986:35:298-291.

40. Forsum E, Hillman PE, Nesheim MC. Effect of energy restriction on total heat production, basal metabolic rate and specific dynamic action of food in rats. J Nutr 1981;111:1691-1697.

41. Chopra IJ. Euthyroid sick syndrome: is it a misnomer? J Clin Endocrinol Metab 1997;82:329-334.

42. O'Mara BA, Dittrich W, Lauterio TJ, St Germain DL. Pretranslational regulation of type | 5?-deiodinase by thyroid hormones and in fasted and diabetic rats. Endocrinology 1993;133:1715-1723.

43. Debaveye Y, Ellger B, Mebis L, Darras VM, Van den Berghe G. Regulation of tissue iodothyronine deiodinase activity in a model of prolonged critical illness. Thyroid 2008;18:551-560.

44. Debaveye Y, Ellger B, Mebis L, Visser TJ, Darras VM, Van den Berghe $G$. Effects of substitution and high-dose thyroid hormone therapy on deiodination, sulfoconjugation, and tissue thyroid hormone levels in prolonged critically ill rabbits. Endocrinology 2008;149:4218-4228.

45. Huang SA, Bianco AC. Reawakened interest in type III iodothyronine deiodinase in critical illness and injury. Nat Clin Pract Endocrinol Metab 2008:4:148-155.

46. Simonides WS, Mulcahey MA, Redout EM, Muller A, Zuidwijk MJ, Visser TJ, Wassen FW, Crescenzi A, da-Silva WS, Harney J, Engel FB, Obregon MJ, Larsen PR, Bianco AC, Huang SA. Hypoxia-inducible factor induces local thyroid hormone inactivation during hypoxic-ischemic disease in rats. J Clin Invest 2008;118:975-983.

47. Lamirand A, Pallud-Mothre $S$, Ramauge $M$, Pierre $M$, Courtin F. Oxidative stress regulates type 3 deiodinase and type 2 deiodinase in cultured rat astrocytes. Endocrinology 2008:149:3713-3721.

48. Kandemir N, Yordam N. Height prognosis in children with late-diagnosed congenital hypothyroidism. Turk J Pediatr 2001;43:303-306.

49. Massa G, de Zegher F, Dooms L, VanderschuerenLodeweyckx M. Hyperthyroidism accelerates growth in Turner syndrome. Acta Paediatr 1992;81:362-364.

50. Esposito S, Prange AJ, Golden RN. The thyroid axis and mood disorders: overview and future prospects. Psychopharmacol Bull 1997:33:205-217.

51. Joffe RT, Levitt AJ. The thyroid and depression. In: Joffe RT, Levitt AJ, eds. The Thyroid Axis and Psychiatric Illness. Washington: American Psychiatric Press, 1993;195-217.
52. Levine $R L$. Endocrine aspects of eating disorders in adolescents. Adolesc Med 2002;13:129-143.

53. Vigersky RA, Loriaux $D L$, Andersen $A E$, Lipsett $M B$. Anorexia nervosa, behavioural and hypothalamic aspects. Clin Endocrinol Metab 1976;5:517-535.

54. Bereket A, Turan S, Karaman MG, Haklar G, Özbay F, Yazgan MY. Height, weight, IGF-1, IGFBP-3, and thyroid functions in prepubertal children with attention deficit hyperactivity disorder: effect of methylphenidate treatment. Horm Res 2005;63:159-164.

55. Ross DS, Daniels GH, Dienstag JL, Ridgway EC. Elevated thyroxine levels due to increased thyroxine binding globulin in acute hepatitis. Am J Med 1983;74:564-569.

56. Schussler GC, Schaffner F, Korn F. Increased serum thyroid hormone binding and decreased free hormone in chronic active liver disease. N Engl J Med 1978;299:510-515.

57. Gardner DF, Carithers RL, Utiger RD. Thyroid function tests in patients with acute and resolved hepatitis $B$ virus infection. Ann Intern Med 1982:96:450-452.

58. Hepner GW, Chopra IJ. Serum thyroid hormone levels in patients with liver disease. Arch Intern Med 1979:139:1117-1120.

59. Kano T, Kojima T, Takahashi T, Muto Y. Serum thyroid hormone levels in patients with fulminant hepatitis: usefulness of $\mathrm{rT3}$ and the rT3/T3 ratio as prognostic indices. Gastroenterol Jpn 1987;22:344-353.

60. Cooper DS, Daniels GH, Ladenson PW, Ridgway EC. Hyperthyroxinemia in patients treated with high dose propranolol. Ann J Med 1982;73:867-871.

61. Felicetta JV, Green WL, Nelp WB. Inhibitoin of hepatic binding of thyroxine by cholesystographic agents. J Clin Invest 1980;65:1032-1040.

62. Mooradian AD, Morley JE. Endocrine dysfunction in chronic renal failure. Arch Intern Med 1984;144:351-353.

63. Mooradian AD, Morley JE, Korchik WK, Ma D, Shafer RB. lodine trapping and organification in patients with chronic renal failure. Eur J Nucl Med 1983;8:495-498.

64. Hardy MJ, Ragbeer SS, Nascimento L. Pituitary thyroid function in chronic renal failure assessed $y$ a highly sensitive thyrotropin assay. J Clin Endocrinol Metab 1988:66:233-236

65. Komaki G, Tamai H, Kiyohara K, Fukino O, Nakagawa T, Mori S, Kumagai LF, Nagataki S. Changes in the hypothalamic-pituitary-thyroid axis during acute starvation in non-obese patients. Endocrinol Jpn 1986;33:303-308.

66. Danforth E Jr, Burger AG. The impact of nutrition on thyroid hormone physiology and action. Annu Rev Nutr 1989:9:201-227.

67. Pugliese M, Lifshitz F, Fort P, Recker B, Ginsberg L. Pituitary-hypothalamic response in adolescents with growth failure due to fear of obesity. J Am Coll Nutr 1987:6:113-120.

68. de Rosa G, Della Casa S, Corsello SM, Ruffilli MP, de Rosa $E$, Pasargiklian E. Thyroid function in altered nutritional state. Exp Clin Endocrinol 1983:82:173-177.

69. Burman KD, Lukes Y, Wright FD, Wartofsky L. Reduction in hepatic triiodothyronine binding capacity induced by fasting. Endocrinology 1977:101:1331-1334.

70. Alemzadeh R, Lifshitz F. Childhood obesity. In: Lifshitz F, ed. Pediatric Endocrinology. New York: Marcel Dekker, 1996:753-774

71. Knudsen N, Laurberg P, Rasmussen LB, Bülow I, Perrild H, Ovesen $L$, Jørgensen T. Small differences in thyroid function may be important for body mass index and the occurrence of obesity in the population. J Clin Endocrinol Metab 2005:90:4019-4024. 